\title{
Socio-cultural impacts of large-scale cruise tourism in Souq Mutrah, Sultanate of Oman
}

\author{
MANUELA GUTBERLET
}

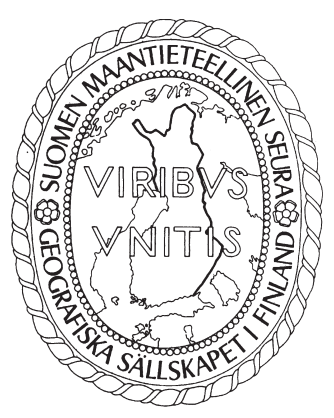

Gutberlet, Manuela (2016). Socio-cultural impacts of large-scale cruise tourism in Souq Mutrah, Sultanate of Oman. Fennia 194: 1, 46-63. ISSN 1798-5617.

The following paper explores socio-cultural impacts of large-scale cruise liner tourism on the traditional bazaar (souq) in the district of Mutrah. The souq is located opposite the port in the Omani capital Muscat. Large-scale cruise tourism in Muscat started only in 2004 and has increased in scale and numbers in the past years. 24 cruise vessels with around 7600 passengers arrived in Muscat in 2005. Seven years later 135 cruise liners carrying 257,000 tourists docked in Muscat. Due to this dramatic rise of international cruise ships, the socio-cultural impacts have increased for local residents, shop vendors/owners and tourists alike. To capture those socio-cultural impacts on Souq Mutrah, a survey of cruise tourists was conducted by a questionnaire. In addition, the researcher used participatory observation, counting, and in-depth interviews with different stakeholders of the local community and different types of tourists during the cruise seasons 2012/13 and 2013/14. Moreover, content analysis of statistics and local media publications were used. Results indicate that the souq has become "the core of a tourist bubble", where crowding is a major problem and local residents avoid the place. The social carrying capacity of the souq has been reached. Omani vendors are leaving their businesses and renting their shops out to expatriates. Since contemporary cruise tourists are low spenders, expatriate shop sellers have become more aggressive.

Keywords: traditional bazaar, cruise tourism, tourist bubble, socio-cultural impacts, local community, Sultanate of Oman

Manuela Gutberlet, RWTH Aachen University, Department of Geography and German University of Technology in Oman/GUtech.E-mail: m_gutberlet@hotmail.com

\section{Introduction}

Cruise tourism has been expanding worldwide. According to the World Tourism Organization (UNWTO), emerging cruise destinations, like the Arabian Peninsula, are gaining ground during the winter season and are competing with the Canary Islands and Azores in the Atlantic (UNWTO 2010: $60)$. Especially the Emirate Dubai is seen as an "emerging cruise hub" (Rodrigue \& Notteboom 2013: 36). "Globally the 13 million cruise passengers recorded in 2004 are expected to increase to 25 million by 2015" (UNWTO 2010: 73). The trend is to raise especially the number of affordable cruises in the so-called 'contemporary' and 'budget' segment. Contemporary cruises are sold as "holiday-at-sea packages" (UNWTO 2010: 61), which are similar to tourist resorts.

Research focusing on cruise tourism and its economic, social and environmental impacts is limited (Stefanidaki \& Lekakou 2012: 81) including its impact on local communities (Weeden et al. 2011: 28; Satta et al. 2014: 54). There is a particular lack of sociological and anthropological studies of cruise tourism (Wood 2000: 347) whereas business, management and economics of cruise tourism have been studied more extensively (Papathanassis \& Beckmann 2011). Existing sociological research on cruise tourist's behavior, for example by Foster (1989), focuses on the behavior of cruise tourists on 
a small cruise liner in the South Pacific while Papathanassis (2012) analyzed the guest-to-guest encounter of German-speaking cruise tourists.

This paper explores the socio-cultural impacts of contemporary cruise tourism in a little researched, emerging cruise destination, the Omani capital Muscat. The paper analyses crowding, and the concepts of cruise tourism as an "environmental bubble" or "tourist bubble" and the "social carrying capacity", i.e. the acceptable social limit of growth (Getz 1987). The concept of the "environmental bubble" introduced by Cohen (1978) focuses on the social, physical and built environment, separated from the surrounding environment. Cohen (1978) mentioned the environmental limits of tourism development. He distinguished four types of factors having an impact on the environment: the intensity of the tourist-site use and the accompanying development of the site, the resilience of the environment, the short-term perspective of the tourism developer and the transformational character of tourism developments (Cohen 1978: 220).

Cohen's concept was further developed by Foster (1989) and Jaakson (2004) as the "tourist bubble". Foster (1989: 223) explored the social interaction of tourists on board a small cruise liner, described as an "air-conditioned bubble". Jaakson (2004) analyzed the tourist environment beside the port in Zihuatanejo (Mexico). His concept of the "tourist bubble" emphasizes the physical and psychological environment of the tourist with his motivations, attitudes and belief system. "A cruise ship is an extreme form of a closed bubble" (Jaakson 2004: 57), where tourists travel in a safe environment of the ship - a comfortable place like home. A cruise ship has been described as a "floating tourist resort, rather than a means of transport" (UNWTO 2010: 1). Weaver (2005a) conceptualized cruise liners as a space of containment, a destination on its own, where tourists spend all their money and time. He also compared the mass-consumption on board a cruise liner with a McDonald's restaurant (Weaver 2005b). According to the UNWTO (2010: 1), the concept of resort-like cruise ships has been very successful in the Caribbean, but cannot be replicated in other regions. Cruise tourists are in almost total isolation on the sea, except when the tourists leave their ship to visit a shore. Wood (2000: 365) mentioned that cruises only "touch down" briefly in their port of call, but spend most of their time in non-territorial waters. One of the activities included in the cruise itinerary are on-shore excursions, organized by local tour operators and conducted in sightseeing buses. Tourists can also stay on board or explore the destination on their own. When they leave the cruise ship they may enter another "tourist bubble" (Jaakson 2004: 57): "Within a bubble there are likely to be significant variations in the concentration of tourists, facilities, services, and activities". According to Jaakson the "tourist bubble" can consist of a single peak representing a core and gradually diminishing contours around it. The periphery zone or the contours may be more complex consisting of multiple peaks (Jaakson 2004: 57).

Most cruise liner research has focused on the economic impact of cruise tourism especially in the Caribbean. According to Wilkinson (1999: 278), cruise tourists in the Caribbean purchase little local products. Similarly cruise tourists in Antarctica (Klein 2010: 67), and Norway (Larsen et al. 2013), stay several hours in the port and spend less money than individual or group tourists who stay longer and spend more money throughout their entire stay. Also Henthorpe (2000) found out that those tourists who spent the least amount of time in a market place spent little money. According to Dwyer and Forsyth (1998), the economic impact of cruise tourism can be attributed to the passenger-related expenditure, crew-related expenditure and companyrelated expenditure. They examined the economic impact of cruise tourism in Australia where tourist expenditure from local cruise liners is higher compared to international cruises. Satta et al. (2014: 72) found out that "there is a positive relationship between word of mouth and the overall satisfaction, and the impact of port-related attributes on the overall satisfaction in Italian cruise ports".

For many countries tourism development can be seen as a process and an important tool to build communities that are economically, socially and culturally prosperous (Wahab \& Pigram 1997: 281). Thus, countries are developing tourism primarily to create jobs and generate further income (Vanhove 1997: 74). However, tourism and particularly enclave tourism is not equally beneficial for all communities. As Cohen (1978: 219) argued, "the development of tourism brings a large number of people, accustomed to a relatively high standard of amenities, to a previously secluded natural or cultural environment". Regarding cruise liner tourism Klein (2010: 66) mentioned that cruise ship tourism has an impact on culturally sensitive locations such as Antarctica, where cruise ship tourism is incompatible with the lifestyle, fa- 
cilities and services of the community. Similarly, in Tonga (Polynesia) (Urbanowicz 1989: 113) and in Dubrovnik (Croatia) the increase in tourist numbers in the old town has been ascribed to the "invasive nature of cruise tourism" (Ljubica \& Dulcic 2012: 27). This phenomenon of a large number of people spending a limited time in the destination has also been called "shock loading" effect (Wilkinson 1999: 277).

Tourism should have benefits for the local community and negative effects on the quality of life should be limited (Krippendorf 1987: 115). The impact of tourism development is defined as "a change in a given state over time as a result of an external stimulus" (Hall \& Lew 2009: 54). To reduce the impacts of tourism, the concept of sustainable tourism has gradually evolved as a social and economic process involving the progressive improvement of conditions and the fulfillment of the potential local community (Wall 1997: 34). The social impacts are effects that influence the values of the community, their behavior patterns, the structure of the community, the overall lifestyle and their quality of life (Hall \& Lew 2009: 57), for example as a result of a large number of tourists. The ways in which local communities cope with the increase in tourism activities depend on the level of the touristic development and if they are affected by it negatively or positively (Doğan 1989: 225). Those who have positive benefits and more satisfying contacts with tourists have also more positive attitudes towards the tourists (Ward \& Berno 2011: 1565). Reactions to tourism are formed through different attitudes such as resistance, retreatism, boundary maintenance, revitalization and adoption (Doğan 1989: 232). According to Doxey's (1976) four-stage irritation index, the host community changes its attitude towards tourism according to the intensity of the tourism development and the number of tourists visiting the place. The perception of socio-cultural impacts can be linked to realistic and symbolic threats involving the competition for limited resources of a community, for example through overcrowding (Ward \& Berno 2011: 1559).

An important indicator for the well-being of the local community is the number of tourists. As Smith (1989: 14) mentioned, the stressful interactions between hosts and tourists appear to increase proportionately to the larger numbers. According to Smith (1989), the critical point in the development of a tourist industry is achieved when tourist facilities are implemented: e.g. special parking for tourist buses, tourist hotels and tourist restaurants. As a consequence, large numbers of tourists can be handled only by industrial methods, for example with standardization and mass production (Krippendorf 1987: 42).

To compensate for negative impacts, Jafari (1987: 158) suggested that tourist generating regions should get financially involved and "pay for some of the impacts of the vacations taken in someone else's backyard". He argued that Europe, for example, owes much to Tunisia and Senegal as their preferred and recreative tourist destinations.

A concept that measures the social, economic, environmental and physical sustainability of a destination is the carrying capacity, defined as "the maximum use of a place without causing negative effects on the resources - the community, the economy and its culture or reducing the visitor satisfaction" (Wahab \& Pigram 1997: 281). The definitions of the physical carrying capacity include numbers of tourists that an area can absorb without negative impact on the physical environment and its limited natural resources and the quality of the tourist experience (O'Reilly 1986; Wall 1997), in addition to the values of the community and (changing) perceptions (Saarinen 2006: 1126). Getz (1987) analyzed six different approaches regarding carrying capacity, one of them was the "social carrying capacity" by using attitudes and tolerance levels of the local community towards tourism development. On the other hand, Saveriades (2000) argued that there is no finite carrying capacity in the number of tourists, since the carrying capacity depends on the overall management of the site, the changes within time and the overall volume of tourism. Saveriades also mentioned that it is difficult to measure the attitudes of the local community in an objective way and that attitudes may change over time (Saveriades 2000: 149), e.g. through adaptation of the host community (Doğan 1989).

Regarding cruise tourism, crowding and congestion were identified as the main social factors influencing the community (Karreman 2013: 66). According to Schemmann (2012), Mediterranean cruise destinations are becoming less attractive as they are often overcrowded in the tourist season. Similarly, ports in Antarctica suffer "people pollution", i.e. the number of cruise passengers exceeds the capacity of the town, thus causing overcrowding (Klein 2010).

In the next sections the rapid development of tourism in Oman will be outlined, followed by the history of Souq Mutrah and an analysis of the re- 
search results, including its "tourist bubble", and of the perceptions of the local community and the German-speaking tourists. The term "local community" is used to refer to shop vendors in Souq Mutrah, business owners, Omani and expatriate customers visiting the souq, local Omani and expatriate tour guides, local tour-operators, residents of the area beside the Souq and local government officials including the Minister of Tourism and the Wali (governor) of the district of Mutrah.

The objective of this research is to conceptualize how locals and tourists perceive large-scale cruise tourism and how they deal with this fast changing phenomenon. Results indicate that crowding has become a major problem and that the perceived social carrying capacity in Souq Mutrah has been reached. This study is valuable for tourism scholars and tourism managers in emerging cruise destinations, especially on the Arabian Peninsula.

\section{Tourism development in Oman}

The Sultanate of Oman is an emerging tourist and cruise destination on the Arabian Peninsula, which has experienced fast economic development since the 1970s. During the 1980s, the country opened its doors for international tourism.

According to the statistics of the Ministry of Tourism (2014) in Oman, in 2013 the number of international tourists increased to 2.18 million. This indicates a growth of $5.9 \%$ between 2012 and 2013. The direct contribution of travel and tourism to the country's GDP was 3.0\% of the total GDP in 2013 (WTTC 2014). The government has been building large-scale tourism infrastructure in order to further increase the number of international tourists to 12 million annually by 2020 (Muscat Daily 2013), which is in line with the neighboring Emirate Dubai that aims to attract 15 million visitors annually by 2015 (Stephenson \& Ali-Knight 2010).

Between 2005 and 2012 the number of cruise liners arriving in Muscat increased more than 80fold. According to the Ministry of Tourism (2012), a total of 109 cruise vessels carrying over 170,000 passengers arrived in 2011, which was nearly equivalent to the total population in Mutrah, the location of the port. There the total number of inhabitants amounted to 189,785 in 2011, only $25.39 \%$ of them being Omani. In 2012, the number of cruise tourists increased again by $51 \%$ to a total of 257,000 arriving in 135 cruise liners at Port Sultan Qaboos in Muscat. In 2013, the number of cruise tourists decreased to 202,159 passengers arriving in Muscat (Ministry of Tourism 2015a).

The majority of the mega ships, such as AIDA and Costa, are on a seven-day trip around the Arabian Peninsula, arriving from Dubai and carrying between 2500 (AIDAblu and AIDAdiva) and 3780 (Costa Favolosa) passengers as well as 600-1000 crew members every week in winter. They stay for around nine hours and then continue their journey via Bahrain, Abu Dhabi and back to Dubai. The vision is to "promote Oman internationally as a quality cruise destination" (Times of Oman 2015b) in cooperation with Abu Dhabi and Dubai as part of a "Cruise Arabia Alliance". Through this cooperation, it has been projected to attract 1.6 million cruise tourists yearly by 2020 and 2.1 million by 2030 (Oman Tribune 2015).

Currently, two or three large cruise liners are in the port at one time. In the coming years the government will transform Port Sultan Qaboos into a cruise liner port, including a marina, a large hotel, a shopping mall and other facilities, in order to accommodate a maximum of 33,000 cruise passengers at one time. All current cargo activities will be shifted to the port in Sohar by 2014 (Oman Daily Observer 2013). Due to tourism projects, new jobs have been created. A total of 106,731 employees worked in tourism in 2013, most of them in restaurants and coffeeshops. However, only $11.2 \%$ of them were Omanis (Ministry of Tourism 2015b).

The Oman Development Plan 1996-2020 specified in the Vision 2020 "aims at achieving sustainable development through the diversification of the economy, without relying solely on oil as the major source of income" (Ministry of Environment and Climate Affairs 2012: 10). The Development Plan focuses on a transition from an oil-based economy to a knowledge-based economy through on-going human development programs in different sectors, including tourism. This is in line with the vision of the Minister of Tourism who wishes "to involve Omanis as a principal pillar in tourism" and to further promote high-end tourism. "We want quality tourism and not tourism of numbers," said Ahmed bin Nasser Al Mahrzi, Minister of Tourism, while adding that Oman wants to preserve its rich history and culture and offer a unique tourist experience (interview, 18 July 2012). This view reflects the general strategy communicated in the local media. However, this is contrary to the ministry's recent marketing efforts that openly pro- 


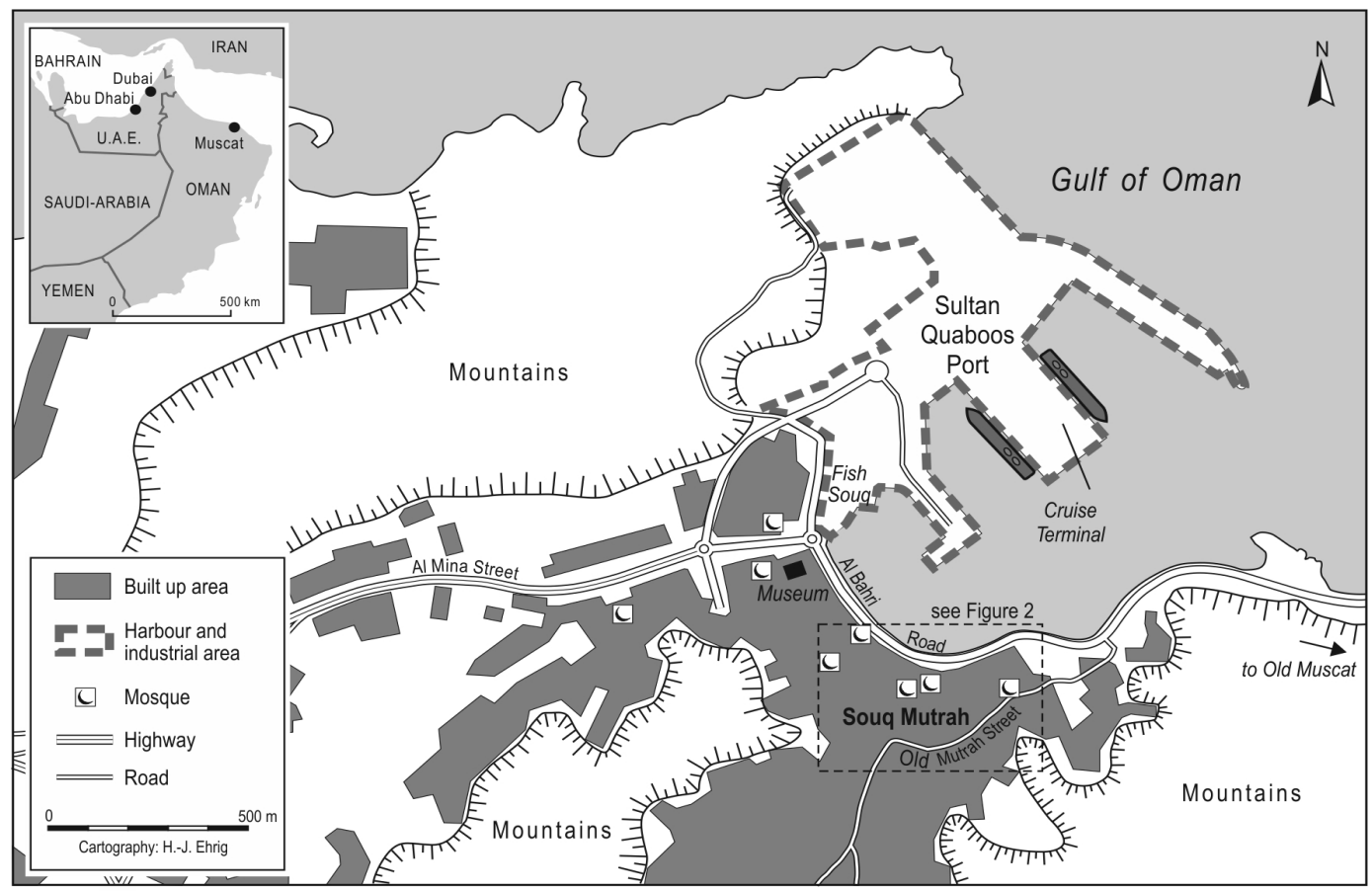

Fig. 1. Map of the district of Mutrah, including Souq Mutrah and Port Sultan Qaboos (source: Ehrig 2014).

mote an increase in large-scale cruise tourism together with Qatar, Abu Dhabi and Dubai. It appears, therefore, that there is lack of a common tourism strategy at the moment.

Furthermore, different stakeholders in the government are involved in the decision-making and execution of tourism development in Oman. Thus, the development of the cruise tourism port and other infrastructure projects such as the airports is overseen by the Ministry of Transportation and Communications. An official of the ministry who chose to remain anonymous said in an interview in July 2014, that the idea is:

"to boost sea-tourism in general, including private yachts. The number of private ships has increased and sometimes they have a difficulty in finding a place. There will be a museum connected to the new fish market, where Omani handicrafts will be showcased. Mutrah will become a nice and safe place to be and to enjoy the sea,"

the official said, thus implying a romantic version of a rather small-scale and high-end city port, avoiding large-scale tourism.

\section{Research setting - the history of Mutrah}

Traditionally, Souq Mutrah (Fig. 1) has been divided into two parts - one for retail and one for wholesale where food, household items, textiles and traditional Omani clothes are sold. Mutrah district has been the main commercial hub of Oman since the Portuguese occupation in the $16^{\text {th }}$ century (Gaube 2012: 4). Due to its commercial activities, Mutrah had a very multi-ethnic population consisting of Arabs, Africans from East Africa and Zanzibar, Baluchis from Baluchistan (province in Pakistan) as well as Persians and Indians. Because most of its inhabitants migrated to Oman in the past, the historically multi-ethnic population of Mutrah has been very welcoming and open to tourism.

Since the 1970s and the reign of Sultan Qaboos bin Said Al Said, the exploration of oil and gas has been followed by the rapid economic development of the country and also the introduction of supermarkets. As a result, Mutrah lost its importance as a commercial hub. Vendors lost their customers and some businesses moved to other dis- 
tricts. Scholz (1990: 298) observed structural changes occurring in Souq Mutrah during the late 1970 s and 1980s when the souq developed from a traditional market predominantly providing textiles, food and household items for locals to a souq that catered more and more to the Asian, Arab and European expatriate community. Nowadays the large majority of the vendors in Mutrah are expatriates from Asia, mainly from India, Pakistan or Bangladesh. Most of them live and work in Mutrah. Until today many Omanis and expatriate residents living in Mutrah buy their groceries in the souq. Due to cheaper prices, Omanis from the Interior of the country also come to shop for household items, local perfumes, textiles and readymade clothes. According to the Wali (governor) of Mutrah, around 800 shops are located in Mutrah and all shops are licensed by Muscat Municipality (interview, 6 October 2012).

\section{Research methods}

The research was conducted in different stages, starting in 2012 with participatory observation and the counting of tourists and locals at the main entrance to the souq on the harbor street (the Corniche), from where the majority enter. There the researcher positioned herself in front of one of the local perfume shops and counted in the morning and afternoon hours with two hand-tally counters in each hand - one for the tourists and the other one for the locals entering during a time-span of 15 minutes per each hour.

Furthermore, in-depth interviews with different stakeholders of the multi-ethnic community were conducted in 2012 and 2013. The interview partners included the local resident community such as shop vendors, business owners, customers, tour guides, tour-operators and government officials including the Minister of Tourism. They were interviewed in English, Arabic and German during 2012 and 2013. The shops were chosen according to prior visits with German-speaking tourists during a walk through the souq. Those shops that were visited along with the tourists were chosen for indepth interviews. The shops covered the wholesale and retail sectors, selling different products: local perfumes, halwa (local sweets), handicraft, pharmacy, spices, groceries, kummas (traditional hats for men), pashmina scarves, foodstuffs, and household items. The owner of a local coffee shop and the manager of a restaurant beside the Souq were also interviewed. A total of 45 shops were covered. The shops were up to 250 years old. In addition, interviews were conducted with the local shop vendors and owners of different age groups (25-75 years) and different nationalities, including 16 Omani, 25 Indian, two Bangladeshi, one Pakistani and one Syrian. Six Omani customers from other districts in Muscat were interviewed. 11 Omani and expatriate tour guides of Germanspeaking tourists and seven Omani male and female members of the resident community living beside the souq were interviewed about cruise tourism in Mutrah. The interviews were conducted in Arabic, English and German and followed a semi-structural guideline. The district was visited on days when one or two mega cruise liners were in the port. Since the access for non-residents is restricted, it was very difficult to conduct interviews. Due to the close social structure of the multi-ethnic community in Mutrah and to allow critical views, the interviews with the local community were taken anonymously and noted down immediately. Follow-up interviews with members of the local community, and observation at the main tourist entrance of Souq Mutrah were conducted at the beginning of 2014, when two contemporary cruise liners (AIDA Cruises and Costa Cruises) were in the port. To capture the impacts visually, photography was applied. Furthermore, the content analysis of local media articles was used and official statistics were analyzed.

A large-scale questionnaire survey among German-speaking contemporary cruise tourists travelling with AIDAblu was conducted at the beginning of 2012. According to a local shipping agency, AIDA Cruises has been transporting around 2500 passengers every week to Oman, from November until April. The first large AIDA cruise liner arrived in Muscat in November 2004 and Costa Cruises followed two years later. The type of tourist carried by AIDA cruise ships is typically the average German-speaking tourist, the so-called "contemporary segment" (UNWTO 2010: 91), representing a couple or family of various age groups with an average income. The research sample was limited to German-speaking cruise tourists from Germany, Switzerland, Austria and Luxembourg. A total of 830 tourists filled out the survey, representing $79.8 \%$ of the surveyed cruise tourist sample. German-speaking tourists represent the majority of cruise tourists visiting Oman. Since the researcher is German national, the research focuses on German-speaking tourists. Moreover, Germans are 
leaders in traveling. According to the UNWTO (2013), Germany ranked second in international tourism expenditure in 2012 and first in 2011.

Since the researcher has studied Arabic and has been living in Oman since 2004 where she worked as a tour guide for German and French-speaking tourist groups in Oman and United Arab Emirates, as well as a reporter for an English and Arabic newspaper and as a PR manager at the German University in Muscat, her research is influenced by her experience. Her insider perspective also helped her to analyze and interpret the different opinions and to observe the changes that have occurred in Souq Mutrah within the past years, from an "insider perspective".

\section{Results}

\section{Cruise tourists visiting Souq Mutrah}

According to local tour operators and a newspaper, Souq Mutrah is the most popular tourist spot in Oman (Times of Oman 2015a). Referring to Jaakson's (2004) analysis of the "tourist bubble", the core area of the "tourist bubble" in Mutrah is the waterfront with its harbor street, the walking promenade (the Corniche) and Souq Mutrah. Along the Corniche road there are ancient trading houses, part of a residential walled district, built around 200 years ago, including a mosque with a blue dome and views to the surrounding mountains (see Fig. 2).

This urban landscape creates a sense of nostalgia of an untouched, postcard-like image of Arabia, different from what tourists see in the other ports of call on the Arabian Peninsula. As Cohen (1978: 218) noted "traditional towns and neighborhoods, untouched by 'progress', suddenly become economic assets". In the past years, the destination Oman including its main cruise liner port in Muscat has been promoted by the Ministry of Tourism with the slogan "Beauty has an address". German-speaking crew members of a contemporary cruise liner mentioned that they recommend Souq Mutrah as a traditional Arabian souq and a "shopping destination". On board of the contemporary cruise liners, small maps are distributed. However, they are not precise, showing only the "tourist bubble" with the harbor street, the souq and old Muscat, located in the next bay. It was observed that tourists were not using the maps.
Many cruise tourists who want to explore the city on their own take a shuttle bus to the gate of the port and walk along the harbor street to the souq. Some tourists also visit the local fish, fruit and vegetable market next to the port and some venture towards the commercial business district of Muscat and others visit a heritage museum close by the port. However, according to the director of the museum only a few tourists from mega cruise liners pass by the museum. The large majority walks along the harbor street, where tourism retail shops selling souvenirs, small restaurants and coffee shops have opened in recent years, and then enters the souq area.

At the harbor street, the main entrance to Souq Mutrah has a large watch-tower with the words "Souq Mutrah" inscribed on it. The tower was built around eight years ago with the arrival of large contemporary cruise liners in Muscat. The tower has a tourist restaurant on the top floor, thus creating a kind of "hyper-reality". Along the waterfront and in the souq area there are open spaces, an "open tourist bubble", shared by locals, residents and tourists. However, the walled residential district beside the harbor road is a closed space, with very limited access.

The researcher's participant observation revealed that, once a cruise liner is in the port for one day, the morning hours between $11 \mathrm{am}$ and $1 \mathrm{pm}$ are the peak timings in Souq Mutrah. Those tourists who have booked a Muscat sightseeing bus tour on board of the cruise liner visit the Souq as part of the excursion. According to local tour operators, those tours are the most popular. Regardless of the number of tourist buses, the tour always follows the same itinerary including Souq Mutrah as the last stop before the return to the harbor. For the tourists' convenience, the buses drive along the one lane Corniche street and stop in front of the main entrance to the souq. Most tourist buses arrive between 11 and 12 noon. As soon as a group of tourists gets in or out of their buses, the road is blocked to traffic entirely. In addition to the large tour buses, smaller buses and $4 \times 4$ cars queue for passengers along the street and create further congestion.

On a Sunday in January 2014, when a Costa cruise ship and an Aida cruise liner were in the port, carrying more than 4000 passengers and crew, participant observation at the entrance to Souq Mutrah revealed that eight large 40-seater buses stopped in front of the main entrance to the soug at noon. At the same time, a large crowd of cruise tourists was waiting in the sun to be picked 


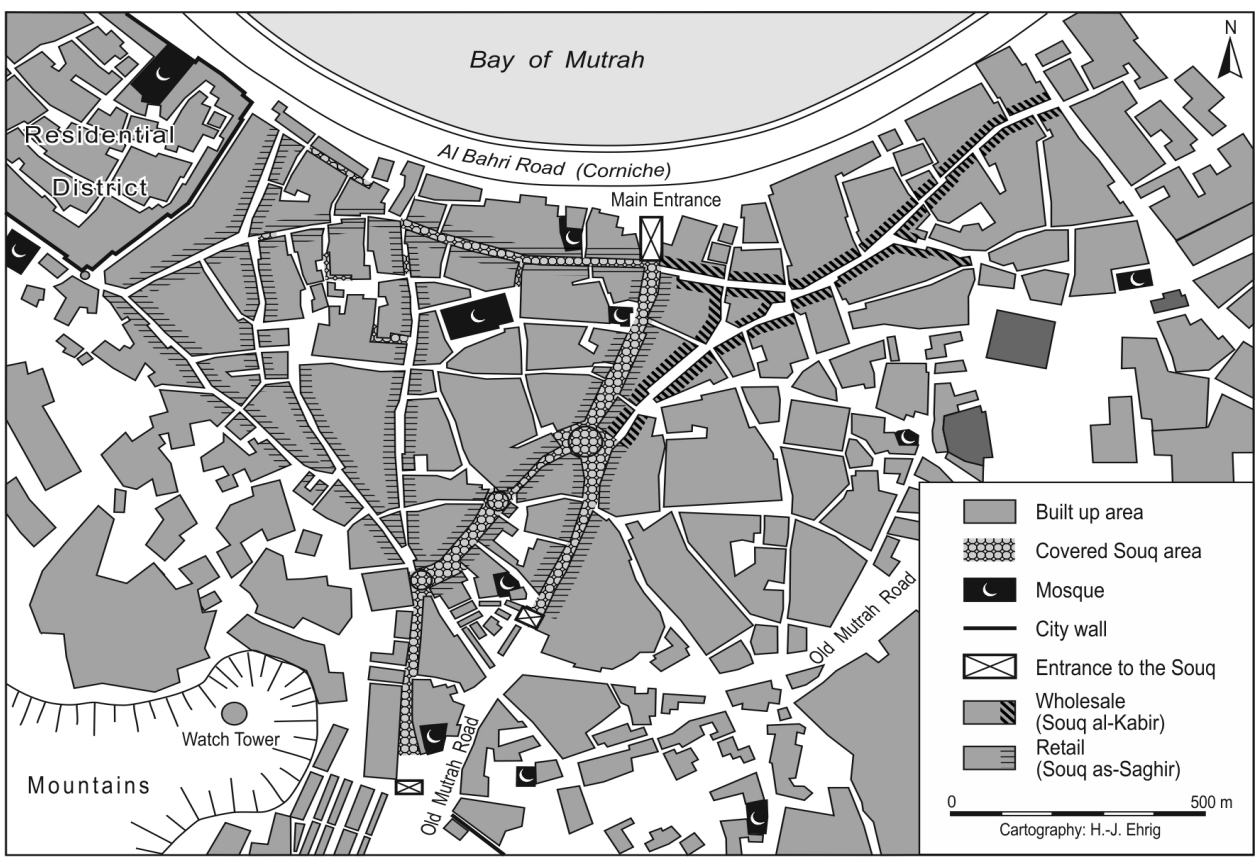

Fig. 2. Map of Souq Mutrah, including the residential area (source: Ehrig 2014).

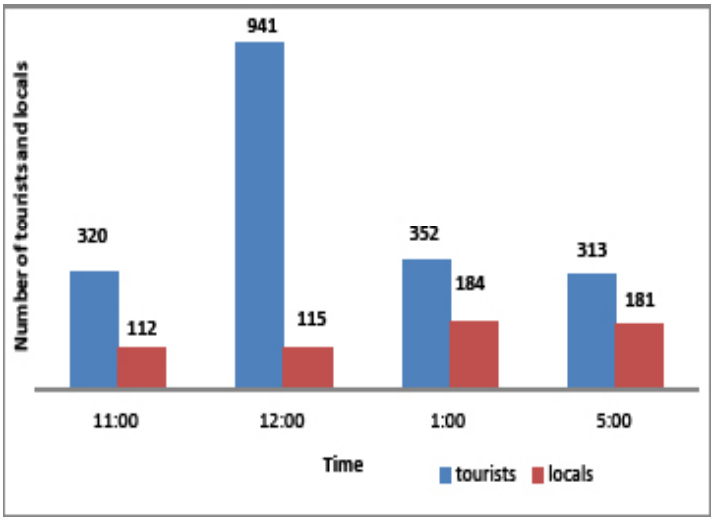

Fig. 3. The number of tourists and locals entering and leaving Souq Mutrah during a time-span of 15 minutes per each hour at main entrance, harbor street, 26 February 2012 (own survey 2012).

up by the buses. This incident revealed lack of adequate parking for buses. Manual counting of tourists, entering through the main entrance at the harbor street every full hour for 15 minutes (Fig. 3), showed major crowding at noon, when the number of tourists was three times as many as the num- ber of tourists arriving at 11 am and at $1 \mathrm{pm}$. In addition, the number of tourists entering the souq exceeded the number of locals by $88 \%$.

Further manual counting on three Sundays in January and February 2012, when two large contemporary cruise liners with a total of more than 4000 tourists were in the port revealed that on average 1371 tourists and 372 locals passed through the main entrance of Souq Mutrah in the morning, between $10 \mathrm{am}$ and $1 \mathrm{pm}$, during a 15 minute count each hour. The majority were tourists from contemporary cruise liners. Figure 4 illustrates the physical crowding of the space, with cruise tourists walking in both directions along the narrow main street of Souq Mutrah around noon.

\section{Perception of the tourists in Souq Mutrah: "There are more tourists than locals"}

Inside the souq different types of tourists meet in close proximity: cruise tourists, individual and group tourists, as well as different nationalities. Whereas contemporary cruise tourists did not socially distinguish themselves from other types of travelers, individual tourists wished to distance themselves, escape from the crowd and venture on 


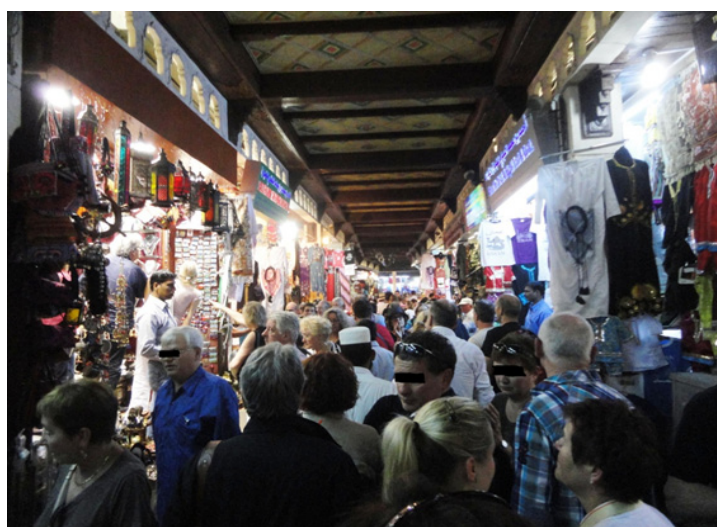

Fig. 4. The main street in Souq Mutrah, 26 February 2012, around noon (photo: Gutberlet 2012).

their own beyond "the tourist bubble" to its periphery. They were the type of traveler defined by Jaakson (2004: 56) as the so-called explorers or elite and off-beat (Smith 1989: 12) that adapt fully or well to the local environment. The reaction of escape and social distinction as a consequence of crowding was observed among most group and independent travelers. For example, an individual tourist, a retired medical doctor in her 60 s said that she was shocked to see the large number of tourists inside the Souq. "I thought the locals are overwhelmed, it is awful. I really feel sorry for them," she said referring to the local community and their tolerance level towards the large number of tourists. "Oh these Italians!" remarked another German-speaking tourist, irritated by a crowd of loudly-chattering Italian cruise tourists.

A retired lawyer in his 70s, travelling with his wife compared the number of tourists and locals inside the souq: "There are more tourists than lo- cals". For him the crowding generated a negative experience and the souq became inauthentic and staged. He also complained about cheap souvenirs: "It is like in Königswinter", he said, referring to a popular tourist attraction beside the river Rhine in Germany. To avoid the crowd, he and his wife along with their tour guide explored the backside of the souq (periphery) where more local shops are located.

A few weeks later, the main street of Souq Mutrah was very crowded, creating a hot, sticky atmosphere: everybody was trying to find their way out. On the edges, some people stopped to look at the souvenir shops. "I need to get out, this is crazy here", said an Austrian lady, starting to panic in the crowd, being afraid that she would not reach the bus back to the ship. Thus, the crowding created lack of safety. This incident confirmed the outcome of the questionnaire survey, where $88 \%$ of the German-speaking cruise tourists surveyed experienced the souq as being too crowded (Table 1).

As a result of crowding, the sanitation facilities were not sufficient for the cruise tourists, who were queuing in front of the few public toilets, located at the entrance to the souq. Some tourists were using the facilities of a hotel or coffee shops along the harbor street. "More than 2000 people are using one or two toilets only," said an expatriate manager of a coffee shop. Thus, he has introduced a "toilet fee", generating an additional income. New tourist infrastructure has been set-up including additional souvenir shops and tourist restaurants with large colorful signboards, artificial grass carpets, wooden chairs and a water fountain, serving international food by expatriate waiters during the tourist season 2013/2014. Cohen (1978: 221) argued that "a concentration of tourist facilities increases the scale of staging functions". Through these visual features, the area has be-

\begin{tabular}{l|l}
\hline "There were too many people in the Souq" & \% of the respondents \\
\hline Agreed strongly & 28.8 \\
Agreed & 32.0 \\
Neutral & 27.5 \\
Disagreed & 9.7 \\
Disagreed strongly & 1.8 \\
\hline
\end{tabular}

Table 1. Attitudes of contemporary German-speaking cruise tourists in Muscat $(\mathrm{N}=721)$ for a statement (own survey 2012). 
come more and more divided into a "tourist bubble" or a "core area" (Jaakson 2004) in the front, close to the port, and a rather local souq in the back and inside the narrow side streets (the periphery).

\section{Attitude of the local tour guides: "Everything has to be fast"}

Unlike group and individual tourists who are usually guided by a tour guide through the souq, cruise tourists are not guided, due to the limited space, time, crowding and increased competition. "With cruise liners everything has to be fast. If I have enough time, I explain the souq in the bus. I only go along with the tourists if it is a small group", said a German-speaking tour guide. Thus, the tour guides remained outside and cruise tourists received limited interpretation of the place. During a city tour cruise tourists have around 3045 minutes time for their visit of the souq. Most cruise tourists remained along the main street of the souq, fearing getting lost inside the street labyrinth. Consequently, they were also not able to locate certain shops, on their own. "Because they have no orientation, the tourists sometimes do not find the spices", said a German-speaking tour guide. Therefore, cruise tourists bought from the product range offered in the "tourist bubble". Tour guides mentioned that they were instructed by their employer, not to go along with the group through the souq. "The shopkeepers think we only direct the tourists to certain shops", said one guide.

\section{Perception of the local shop keepers: "The tourists are just looking"}

Since the start of large-scale cruise tourism in Muscat in 2004, the business community has noticed a sharp increase in tourist numbers. "Sometimes about 3000 tourists pass here in this small street", complained one member of the long-established business community. Another Asian shop manager said: "There are so many tourists. It is difficult to walk".

The shop owners and sellers in Mutrah are disappointed about the tourism development in the souq. "These are not the tourists we were told are coming to Oman. We are focusing on numbers rather than on quality. But the number of tourists reduces the quality of tourism", said an Omani. The cruise tourists buy souvenirs along the main street of the souq, they gaze and they take photos: "They just do a tour and then go", said a local shop owner. Other vendors expressed similar disappointment. "We have only had two customers from a cruise liner", said an Omani in the gold souq, located on the backside of the souq, in the periphery of the "tourist bubble". Omani taxi drivers who are located close to the main entrance to Souq Mutrah complained that the main profit of cruise liner tourism goes to the local tour operators, shipping agents and to the port authority. They mentioned that cruise tourists were not interested in taking a taxi and ventured on their own along the Corniche road.

Nevertheless, the majority of the interviewees of the local business community mentioned being in favor of the planned cruise liner port, but on a much smaller scale: "Three large cruise liners per week, not per day", were suggested. Moreover, there is a wish for a common tourism development plan in Souq Mutrah: "We need a common vision. How will we cope with the influx of tourists in a couple of years when the port will be a tourist port? We are already struggling now with more than 100 tourist ships in the winter season", said a shop-owner of the long-established Indian trader community. Due to over-crowding and lack of parking, local Omani and expat customers who went shopping in Souq Mutrah in the past now avoided the souq. "When cruise liners are in Muscat, I do not visit the souq anymore", said an expatriate resident.

With the increase in large cruise ships, the shop vendors have observed a change in the tourist spending behavior. "They are tourists, but without money", said a well-established Indian shop owner. An Indian vendor from the harbor street complained: "The tourists are just looking, they do not buy anything. Only those who come by airplane buy here", he said. This confirms the results of a low-spending behavior of cruise tourists, discussed by Wilkinson (1999), Henthorpe (2000), Weaver (2005a), Klein (2010) and Larsen et al. (2013). Shops located inside the souq on the periphery of the "tourist bubble", in the small narrow side streets of the souq, do not benefit as much from cruise tourism. Only the "new vendors" from Asia, who have started working in the souq recently, since the arrival of large-scale cruises, valued the large number of tourists as "a business opportunity, rather than a loss of culture" (Hall \& Rath 2007: 18). They have adapted their product range to the taste and budget of the cruise customers. 
A pattern of low spending among Germanspeaking cruise tourists was confirmed in the questionnaire survey. Figure 5 shows that $40 \%$ of the cruise tourists who responded did not spend anything in Souq Mutrah ( $\mathrm{N}=760)$ and nearly $60 \%$ have spent only a small amount. $32.7 \%$ spent less than 20 Euro, while just $1.7 \%$ spent more than 100 Euro. Thus cruise tourists were not primarily interested in buying local and more expensive souvenirs. This was confirmed in interviews: "We have already bought a lot in Istanbul. We will not buy anything here", said a 30-year-old Austrian cruise tourist from Costa. A German couple travelling with MS Europa luxury cruise liner said that "they do not need anything" and that the shops were selling the same items as in the popular tourist destination Spain. "They are selling pashminas in large quantities in Spain", he said.

According to the survey, the majority of the German-speaking tourists from the mega cruise liner $(\mathrm{N}=691)$ had bought small and less expensive souvenirs, most of them not locally made: $43 \%$ had bought pashmina scarves (usually replicated pashminas made in China), followed by Omani frankincense $(22.3 \%)$, postcards $(21.8 \%)$ and other small items (16.5\%) including belly dancing dresses, dates, oil lamps, perfume oils, medicine from the pharmacy, key-chains, magnets, ashtrays and T-shirts (see Fig. 6). Typical Omani products that are also bought by locals, such as a dishdasha and turban $(6.5 \%)$, gold and silver $(7.3 \%)$, or khanjars $(2.0 \%)$ were rarely purchased by the cruise tourists surveyed. This also confirm the results of previous research conducted by Larsen et al. (2013) who found that cruise tourists are low spenders compared to other tourists who stay longer in the destination. Klein (2010: 67) also stressed that the onshore spending of cruise tourists has declined in the past years.

Due to the rising demand, the number of shops selling cheap, imported items has increased inside the "tourist bubble". "Unfortunately they are selling pashminas and elephants from Thailand. It has become like a textile souq. We see more T-shirts with 'I love Oman' or Indian saris", complained an Omani tour guide.

As a consequence of the tourists' low spending behavior, the vendor community has changed their selling approach and become more aggressive, which annoys some German-speaking group and individual tourists. "Vendors along the main street approached us in a very aggressive way. We were not interested in their items. We just wanted to leave", said an individual tourist. In January 2014 along the "tourist bubble" young Asian vendors who had worked only from inside their shops in recent years started hiring additional sales people who were to hawk their items outside the shop: "Madam, look pashmina scarf! Frankincense, saffron and perfume", Asian vendors call out in Eng-
Fig. 5. Spending behavior of Germanspeaking cruise tourists in Muscat $(\mathrm{N}=760)$ (own survey 2012).

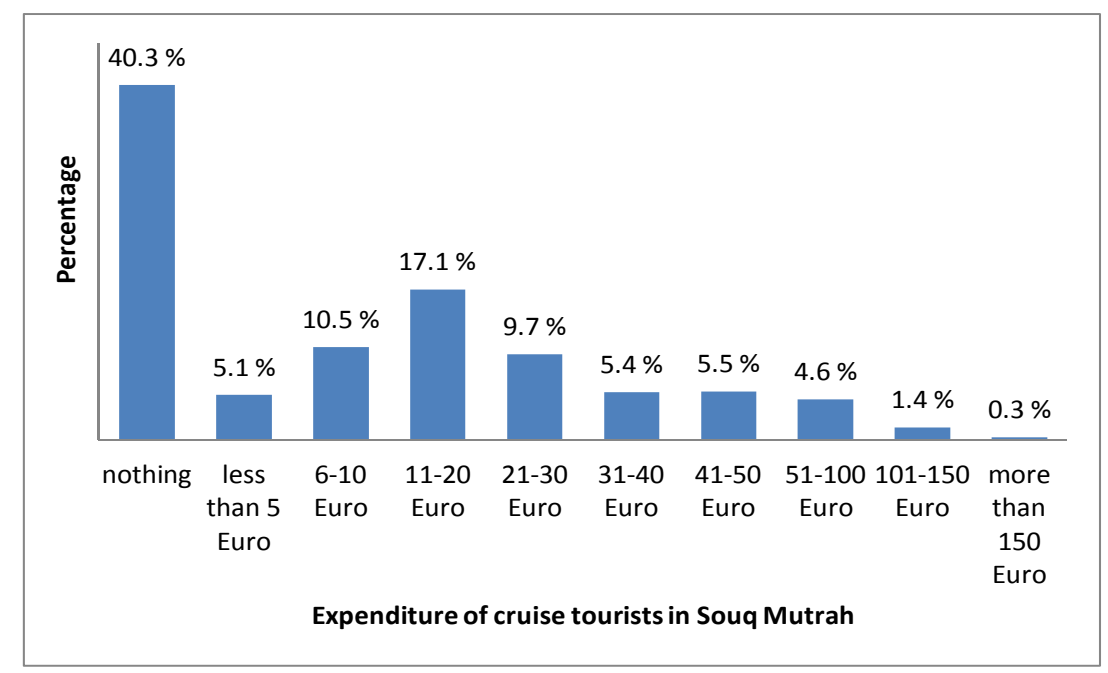


lish, German and Italian while holding a scarf along with a perfume bottle (Fig. 7) in their hands. In Oman it is known that Asian businessmen have a rather aggressive selling behavior whereas Omanis have a softer selling approach (Gutberlet 2008). "If someone is interested in my shop I say welcome, but I don't pull him inside the shop", said an Omani who owns a shop in the "tourist bubble". The growth in the number of expatriate vendors has led to ethnic tension and stereotyping: "I do not go in the street to sell, only Indians are doing this", said an Omani vendor.

Some tourists who were guided appreciated the kind approach and hospitality of the local Omani vendors: "The locals are very friendly, not so pushy like in Turkey. They ask first whether you want to buy anything and then they explain everything", said an individual traveller in his 50s, who was guided by a local tour guide.

As a consequence of the expatriate vendors' aggressive selling practices, in March 2014 local vendors along the harbor street were officially instructed by the inspectors of Muscat Municipality to remove their items from outside the shops, oth-

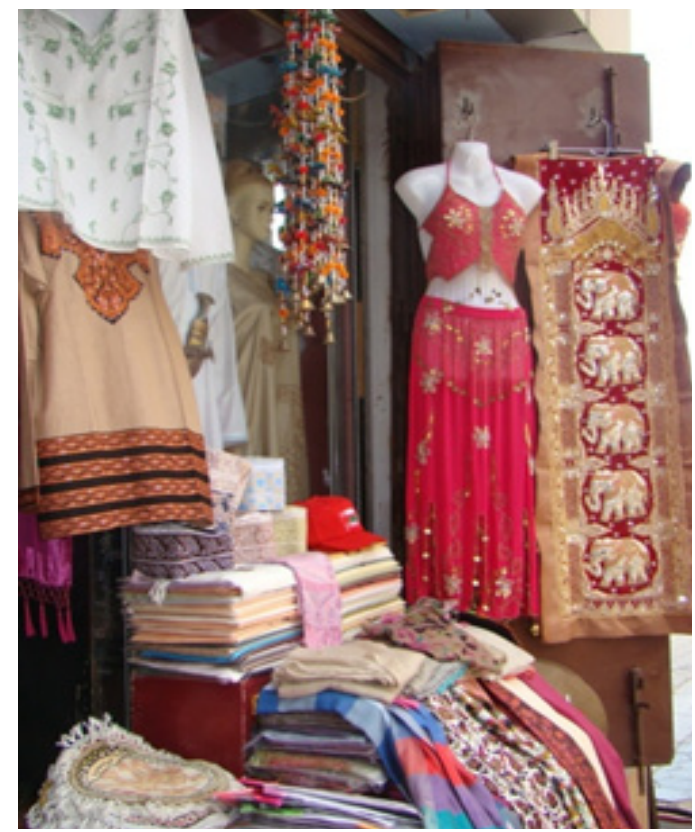

Fig. 6. Imported souvenirs, displayed outside a shop at the entrance to Souq Mutrah (photo: Gutberlet 2013). erwise they would be fined (Times of Oman 2014). As a result it was observed that the expatriate vendors had adopted a more passive approach.

\section{Silent resistance}

The remaining well-established Omani and expatriate businessmen in Mutrah have developed a silent resistance and passive attitude towards tourists and mass tourism products. As a consequence of this resistance, shops that cater for Omanis and their product range of groceries, embroidery, halwa (Omani sweets), dishdasha (Omani male clothing), kummah (male cap) and masar (turban) and other accessories are relocating from the main street to the interior, the periphery of the "tourist bubble". This phenomenon was observed at the entrance to the main street, where a local shop owner selling perfumes, textiles and embroidery for the local community (Fig. 8) for the past 40 years moved to the inside of the souq in 2014 and converted into a tourist shop, selling pashmina scarves, Indian textiles, postcards, carpets and belly dancing costumes (Fig. 9 ).

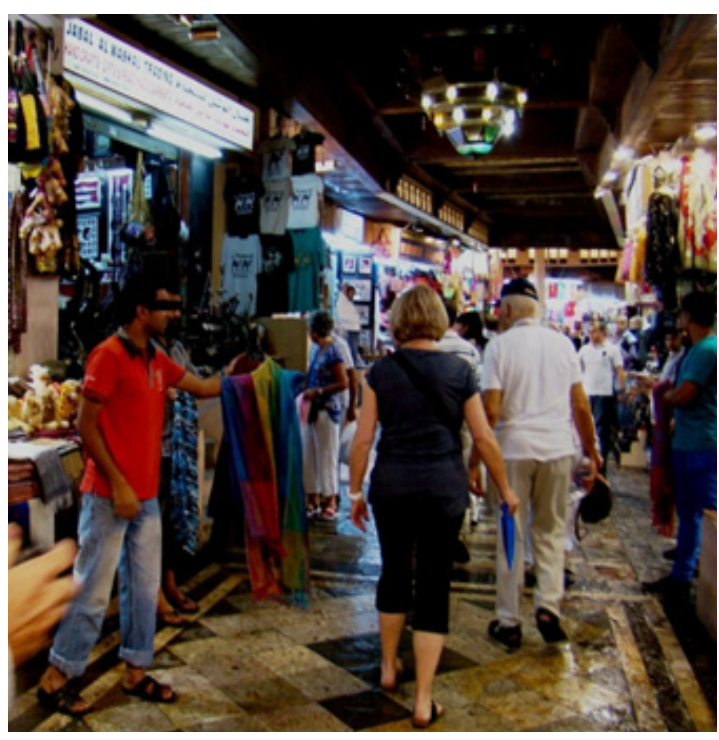

Fig. 7. An expatriate vendor approaches a female tourist with a scarf (photo: Gutberlet 2014). 


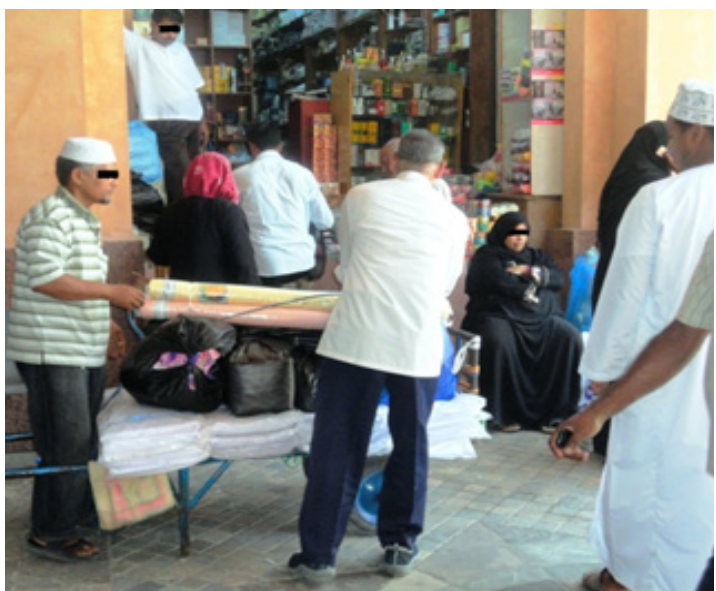

Fig. 8. Shop for the local community at the entrance to the Souq (photo: Gutberlet January 2013).

The Indian vendor, who has been working in Mutrah in the second generation, continues selling items for the local Omani market from his shop inside the souq. Similarly, in the same year another Omani shop on the main street selling khanjars and locally produced items, was converted into a shop selling mainly pashmina scarves. Also the Omani owner and vendor left his shop and expatriate vendors took over. The change in the social structure has been described as a long-term process: "Before 1970 the shop keepers were 100 per cent Omani. That has changed, now less than 5 per cent are Omanis, the majority is foreigners", said an Omani owner of a traditional halwa shop, who is in his 60s.

A 150-200-year-old Omani herbal and spice shop in the center of Souq Mutrah closed in 2013. The shop was very popular among Western tourists and locals, due to its authentic interior and a variety of local items. It was renovated at the beginning of 2014 and the shop was offered for rent for banking ATM machines. "We have to move on", said the owner, thus stressing the need to transform the souq into a modern shopping street. Two years earlier, however, the same shop-keeper had mentioned in an interview that the shops and their identity in Souq Mutrah need to be protected.

With an increase in the number of tourists visiting an Omani souq, a high ranking government official claimed in an interview that: "If foreigners go to the local souq, they will kill it" referring to

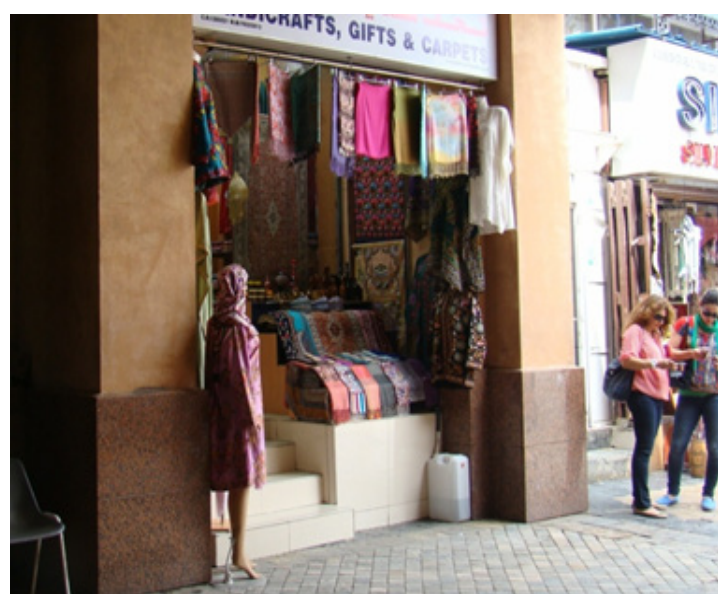

Fig. 9. The same local shop was converted into a tourist shop one year later (photo: Gutberlet January 2014).

the loss of local identity. This reflects the fear of being overwhelmed by the large number of tourists and of losing their cultural identity.

All these observations are significant. Translated in Doxey's (1976) irritation index, the business community shows a desire to escape and a degree of irritation. In addition, there is a decrease in the number of shops selling products for the local community, so the "tourist bubble" has been extended. The attitudes of the local established business community who own the shops reflect their views towards getting the greatest financial benefits out of tourism development. On the other hand, such transformation of businesses had already occurred in the past in Souq Mutrah. Scholz (1990: 257, 384) mentioned that local food products and turbans were still sold in Mutrah during the early 1970s, but also recorded the rapid economic and social changes that occurred from the 1970 s onwards, with the increasing demand for "new imported products".

\section{The attitude of local residents}

To protect themselves from the large number of tourists walking in front of their houses, some residents have created further physical and social boundaries. The old residential walled district opposite the port, which is featured in many tourism advertisements, with its ancient and beautiful trading houses has a guard sitting beside the entrance gate. The guard re- 
fuses access to those who do not belong to the community. However, the entrance from the backside of the souq has no guard. Furthermore, a signboard "Residential Area" indicates that entry is restricted. During the annual religious month of Al Muharram, celebrated by the resident Muslim Shia community, which has taken place during the busy tourist season in the past years, the community has set up a white wall in front of the entrance gate (Fig. 10), in order to maintain their privacy and to protect themselves from curious onlookers.

This observation of creating boundaries was reinforced whenever the place was entered and the researcher was asked to leave the place: "This is a residential place, shopping over there", said an Omani lady, indicating a clear refusal to have sightseers inside the historic walled district. That was confirmed by Omanis who do not belong to the community, who mentioned that they are also unwelcome inside the district. Furthermore, the researcher was asked by local male Omani residents who work in Souq Mutrah to cover her hair when entering the walled district, which is not an obligation to female expatriates and tourists in Oman. This indicates a conservative attitude and reinforcement of the community's values. Moreover, four signboards have been set up beside the entrance of the mosque, thus preventing non-resi- dents from entering the residential area and nonMuslims for entering the mosque, located on the harbor street, opposite to the port. Therefore, the community has clearly defined a distinction and draws additional borders between the residents and the outsiders - non-residents and tourists alike. "The families are more religion-minded and not tourism-minded", explained a member of the community, indicating that there is no interest in opening the district for outsiders.

An official measure against the congestion of the public space in Mutrah was the setting up of a large red signboard by Muscat Municipality in front of the souq, just before the tourist season 2013/2014. The signboard prohibits local vendors and customers from loading and unloading trucks during the peak timings in the morning and in the afternoon, thus restricting the purchase of local customers who buy in large quantities during that time.

\section{Conclusions}

Although this research is a snapshot taken during a particular time and location, it is important since it reflects the views of both the local community and of tourists at a time of substantial increase in tourist numbers, in particular cruise tourists. This re-
Fig. 10. An additional white wall (center) was set up in front of the residential district, the Corniche road (photo: Gutberlet 2013).

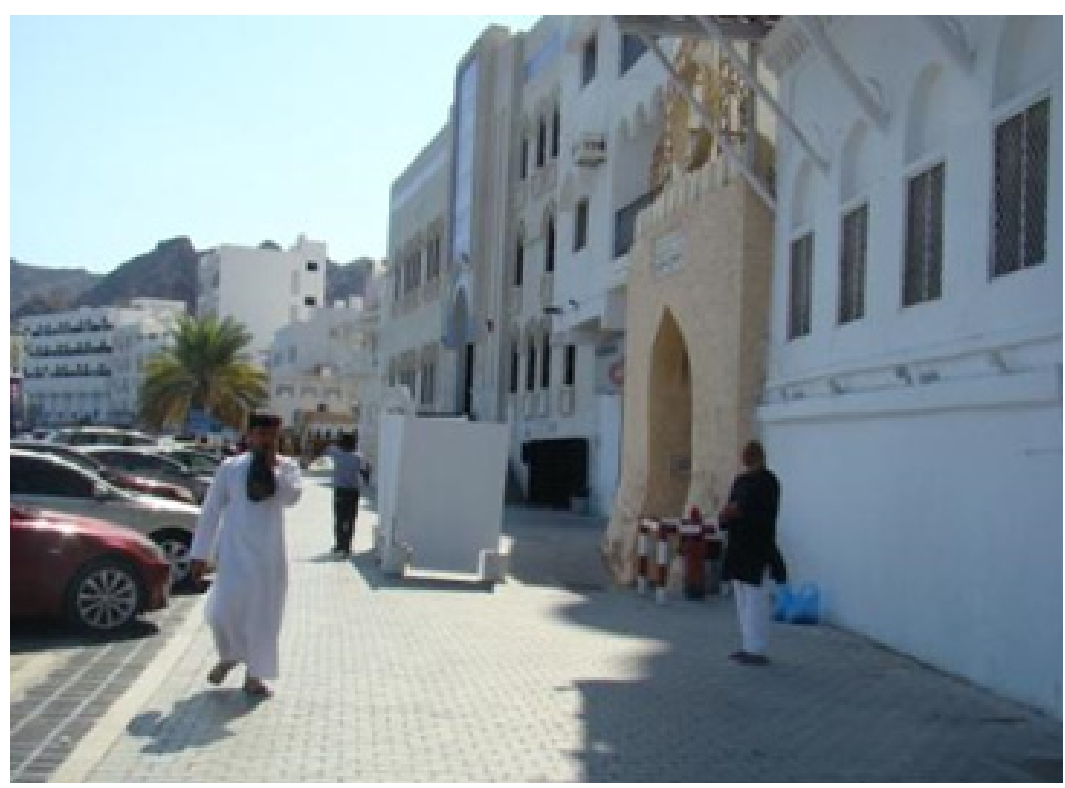


search has been conducted right before the start of a major large-scale tourism development - the cruise liner port, which will be built opposite the souq, doubling the number of ship berths and raising the overall capacity for passengers enormously. As a consequence, the social and cultural pressure on the local community will increase as well. As a result of this research it has become clear that due to the influx in cruise tourism in the past years, the historic district along the harbor road and Souq Mutrah have been commodified and become a reflection of the "tourist bubble" (Jaakson 2004), a "place to be" for cruise tourists, absorbing and processing a large number of tourists during the cruise season. Therefore, the district has lost its "simple charm" and is generally avoided by local residents when a large cruise liner is in the port. It is evident that the souq is divided into a "core tourist bubble" in the front, close to the harbor and along the main street of Souq Mutrah, and a local souq for the Omani and expatriate residents in the back, on the periphery of the "tourist bubble". The front section of the souq has become a reflection of MacCannell's (1992) "Empty Meeting Grounds" where tourists do not meet locals, but a kind of "Show-Souq" with cheap, foreign commodified mass products and "new Asian vendors", who represent Oman.

Furthermore, the souq has become overcrowded when two large contemporary cruise liners are in the port, conceptualized as "shock loading effect" (Wilkinson 1999). Crowding has occurred due to the spatial and temporal distribution of the cruise tourists, the limited urban geography and the limited number of tourist sights close to the port. It seems that the increase in the number of cruise tourists arriving by cruise liners in Muscat has been unexpected and surprising for the local community in Mutrah and for other tourists, both group and individual, without considerations regarding the social, cultural and physical impacts and the limited space and infrastructure.

According to the majority of the community and the tourists surveyed, there is "no more room" for more tourists inside the souq. Thus, locals mentioned that the authorities should limit the number of annual visitors, since their accepted level of tolerance and "perceived social carrying capacity" has been reached. As a consequence and translated in Doxey's (1976) irritation index, the local population escape, either by withdrawing from the core of the "tourist bubble" or by creating borders to protect themselves from curious onlookers. Re- ferring to a transformation into a tourist place, Orbasli (2000: 109) mentioned: "Citizens may become alienated as the old towns are transformed into tourist attractions with the focus on visitors, 'outsider' needs rather than those of residents". Currently, negative impacts such as over-crowding, the sale of cheap mass-products, and an increasing loss of Omani identity seem to outweigh the economic and social benefits for the majority of the local community.

To avoid crowding and to release the pressure on the local community, a quota for large-scale cruise liners arriving in Port Sultan Qaboos in Muscat should be set up and strictly monitored. Visits to Souq Mutrah should be controlled at the entrance and other sightseeing options should be included in sightseeing tours, for example a special Tourist Souq could be set up inside the port to ease the congestion outside the port. To increase the revenue for the local community, only small, luxury cruise liners, that do not offer all-inclusive holidays on board, should anchor in Muscat. Moreover, cruises should be encouraged to stay overnight. This would also allow for additional excursions around Muscat. In addition, as Jafari (1987) suggested the tourists and cruise companies should compensate negative effects on the community and should get financially involved. For example a daily tourism tax for cruise liners could be introduced, e.g. 10 Euro per person per day, which could then be reinvested into local community development. A pro-active management plan and regulations need to be implemented, under local control and results continuously updated. "The local people and communities should have the right to choose their way of life and preferences" (Saarinen 2011: 155). Commercial pressure dominating the development of the souq, including the changing product range on sale, leads to the loss of local heritage, and should therefore be avoided. Responsible tourism planning should include the development of tourism with dignity for the local community. This includes controlling the carrying capacity and the development of the local production of goods by supporting independent local businesses. Moreover, this could include the re-branding of the souq as a multi-ethnic place including e.g. ethnic supermarkets and book shops (Hall \& Rath 2007). Thus, a social, cultural and economic empowerment of the entire multi-ethnic community inclusive of all stakeholders should be set up, through the creation of special committees such as Mutrah Tourism 
Committee and a "local cruise committee" (Hull \& Milne 2010:187). Members of such a committee should include The Port Authority, the Municipality, the Ministry of Transportation and Communication, Royal Oman Police, the Ministry of Tourism, the Public Authority for Handicraft, shipping agents, tour operators, tour guides, business owners and vendors in Mutrah. Through open participation such "local cruise committee" could then develop a set of sustainable tourism development indicators (Torres-Delgado \& Saarinen 2014). These social indicators should reflect the needs of the local community, including for example the number of cruise tourist arrivals per day, the ratio of tourists and locals, the sale of local products and the employment rate. Moreover, to ensure valuable positive results for the community it is necessary to implement and monitor the indicators continuously.

This research has certain limitations arising from the research methodology. While a broad range of members of the local community in Mutrah were interviewed, in particular the shop vendors and owners, no quantitative survey was conducted among the community. Also the number of tourists interviewed can be seen as small and insufficient for generating conclusions. However, despite these limitations, from the survey and the in-depth interviews, interesting issues on large-scale tourism in Mutrah have emerged and suggest further research in the field in Mutrah, e.g. including more shops along the Corniche road and among more female members of the community. Due to the fast pace of the tourism development in Mutrah, it would be interesting to record the changes through regular, continuous field research and participant observation. This research can be seen as an exemplary case study that can be applied to other tourism developments in Oman in the future.

A businessman and owner of a group of companies in Oman who grew up and lived in Mutrah until the 1970s said: "We need more time for local people to become aware that tourists are not going to attack them but admire them". However, the time is very limited and meanwhile the number of cruise tourists will continue to increase. For the tourist season $2014 / 2015$ a growth of $10-15 \%$ is expected in cruise tourism (Times of Oman 2015b).

Feb. 2012, 6 pm: The ship's bell rings, the sun is disappearing over the horizon as the large Costa cruise ship moves towards the exit of the port. It is peaceful in the souq. Omanis go quietly about their business. The ship is brilliantly lit with lights from every porthole, and flash lights illuminate the darkness around it as the last photos of Mutrah are taken by the departing tourists. The muezzin calls the faithful to prayer. The ship leaves the port and turns left towards Fujairah and Dubai. The cruise tourists will soon proceed to their dinner. Along the waterfront expatriate workers take a few photos of the cruise liner with their mobile phones. The ship has left the harbor and the sun has set. The souq belongs to the local community again.

\section{ACKNOWLEDGEMENTS}

I would like to thank Jarkko Saarinen, the coordinating editor, for encouraging me to submit this paper. Furthermore, I would like to acknowledge the advice and support throughout this research of Carmella Pfaffenbach. I also would like to acknowledge all support of the local community and of the AIDAblu cruise liner. Moreover, I am grateful for the valuable comments of all anonymous reviewers.Finally, I would like to thank the German University of Technology in Oman for their support.

\section{REFERENCES}

Cohen E 1978. The impact of tourism on the physical environment. Annals of Tourism Research 5: 2, 215-237. http://dx.doi.org/10.1016/0160-7383(78)90221-9.

Doğan HZ 1989. Forms of adjustment. Sociocultural impacts of tourism. Annals of Tourism Research 16: 2, 216-236.

http://dx.doi.org/10.1016/0160-7383(89)90069-8.

Doxey G 1976. When enough's enough: the natives are restless in Old Niagra. Heritage Canada 2: 2, 26-37.

Dwyer L \& Forsyth P 1998. Economic significance of cruise tourism. Annals of Tourism Research 25: 2, 393-415. http://dx.doi.org/10.1016/S0160-7383 (97)00098-4.

Foster GM 1989. South seas cruise a case study of a short-lived society. Annals of Tourism Research 13: 2, 215-238.

http://dx.doi.org/10.1016/0160-7383(86)90038-1.

Gaube H 2012. Mutrah redevelopment master plan. Cultural heritage stage 2. Conclusions and recommendations. Working paper 20. Norplan AS, Norway and Middle East.

Getz D 1987. Capacity to absorb tourism - concepts and implications for strategic planning. Annals of Tourism Research 10: 2, 239-261. http://dx.doi.org/10.1016/0160-7383(78)90221-9.

Gutberlet M 2008. Verhandeln mit Geschaeftspartnern in Oman. In Brenner $\mathrm{H}$ (ed). Praxishandbuch fuer Exportmanager, 1-16. Deutscher Wirtschaftsdienst, Köln.

Hall M \& Lew A 2009. Understanding and managing tourism impacts: an integrated approach. Routledge, London. 
Hall M \& Rath J 2007. Tourism, migration and place advantage in the global cultural economy. In Rath J (ed). Tourism, ethnic diversity and the city, 1-24. Routledge, New York and Oxon.

Henthorpe T 2000. An analysis of expenditures by cruise ship passengers in Jamaica. Journal of Travel Research 38: 3, 246-250.

http://dx.doi.org/10.1177/004728750003800306.

Hull JS \& Milne S 2010. Port readiness planning in the Arctic: building community support. In Lück M, Maher PT \& Stewart EJ (eds). Cruise tourism in Polar regions. Promoting environmental and social sustainability?, 181-204. Earthscan, London.

Ehrig, HJ 2014. Maps of Mutrah. RWTH Aachen University, Department of Geography, Aachen.

Jaakson R 2004. Beyond the tourist bubble? Cruiseship passengers in port. Annals of Tourism Research 31: 1, 44-60.

http://dx.doi.org/10.1016/j.annals.2003.08.003.

Jafari J 1987. Tourism models: the sociocultural aspects. Tourism Management 8: 2, 151-159. http://dx.doi.org/10.1016/0261-5177(87)90023-9.

Karreman J 2013. Cruise tourism development in a small destination. Lambert Academic Publishing, Saarbrucken.

Klein RA 2010. Cruises and bruises: safety, security and social issues on Polar cruises. In Lück, Maher PT \& Stewart EJ (eds). Cruise tourism in Polar regions. Promoting environmental and social sustainability?, 57-74. Earthscan, London.

Krippendorf J 1987. The holiday makers. Understanding the impact of leisure and travel. Heinemann Ltd., London.

Larsen S, Wolff K, Marnburg E \& Ogaard T 2013. Belly full, purse closed. Cruise passenger's expenditures. Tourism Management Perspectives 6, 142-148. http://dx.doi.org/10.1016/j.tmp.2013.02.002.

Ljubica J \& Dulcic Z 2012. Megaships and developing cultural tourism in Dubrovnik. In Papathanassis A, Lukovic T \& Vogel M (eds). Cruise tourism and society, 17-28. Springer Verlag, Berlin.

MacCannell D 1992. Empty meeting grounds: the tourist papers. Routledge, London.

Ministry of Environment and Climate Affairs 2012. The national report on sustainable development Rio - Brazil. Committee for Sustainable Development chaired by the Undersecretary of the Ministry of Environment and Climate Affairs, Muscat.

Ministry of Tourism 2012. Cruise liner arrivals in Muscat. Statistics from the Directorate General of Planning, Follow-up \& Information, Ministry of Tourism, Muscat.

Ministry of Tourism 2014. Number of tourists to Oman 2011-2013. Statistics from the Directorate General of Planning, Follow-up \& Information, Ministry of Tourism, Muscat.

Ministry of Tourism 2015a. Number of cruise tourists arriving in Muscat 2013-2015. Statistics from the Directorate General of Planning, Follow-up \& Information, Ministry of Tourism, Muscat.
Ministry of Tourism 2015b. Employment in the tourism sector in Oman end of 2013. Statistics from the Directorate General of Planning, Follow-up \& Information, Ministry of Tourism, Muscat.

Muscat Daily 2013. Oman wants tourism sector to contribute to $3 \%$ of GDP by 2020. Muscat Daily, 26.06.2013.

Oman Daily Observer 2013. Deadline set for cargo vessels at port. Oman Daily Observer, 07.10.2013.

Oman Tribune 2015. Number of cruise tourists rising, to hit $1.6 \mathrm{~m}$ in 2020. Oman Tribune, 18.02.2015.

O'Reilly AM 1986. Tourism carrying capacity: concepts and issues. Tourism Management 7: 4, 254-258. http://dx.doi.org/10.1016/0261-5177(86)90035-X.

Orbasli A 2000. Tourists in historic towns. Urban conservation and heritage management. Taylor \& Francis, New York.

Papathanassis G \& Beckmann I 2011. Assessing the 'poverty of cruise theory' hypothesis. Annals of Tourism Research 38: 1, 153-174.

http://dx.doi.org/10.1016/j.annals.2010.07.015.

Papathanassis G 2012. Guest-to-guest interaction on board cruise ships: exploring social dynamics and the role of situational factors. Tourism Management 33: 5, 1148-1158.

http://dx.doi.org/10.1016/j.tourman.2011.11.016.

Rodrigue J-P \& Notteboom T 2013. The geography of cruises: itineraries not destinations. Applied $\mathrm{Ge}$ ography 38, 31-42.

http://dx.doi.org/10.1016/j.apgeog.2012.11.011.

Saarinen J 2006. Traditions of sustainability in tourism studies. Annals of Tourism Research 33: 4, 1121-1140.

http://dx.doi.org/10.1016/j.annals.2006.06.007.

Saarinen J 2011. Tourism development and local communities: the direct benefits of tourism to Ovahimba communities in the Kaokoland, Northwest Namibia. Tourism Review International 15: 1-2, 149-157. http://dx.doi.org/10.3727/15442721 1 X13139345020534.

Satta G, Parola F, Penco L \& Persico L 2014. Word of mouth and satisfaction in cruise port destinations. Tourism Geographies: An International Journal of Tourism Space, Place and Environment 17: 1, 54-75. http://dx.doi.org/10.1080/14616688.2014.938689.

Saveriades A 2000. Establishing the social tourism carrying capacity for the tourist resorts of the east coast of the Republic of Cyprus. Tourism Management 21: 2, 147-156. http://dx.doi.org/10.1016/ S0261-5177 (99)00044-8.

Schemmann B 2012. User-driven innovation concepts and the cruise industry. In Papathanassis A, Lukovic T \& Vogel M (eds). Cruise tourism and society, 153-172. Springer Verlag, Berlin.

Scholz F 1990. MUSCAT Sultanat Oman. Geographische Skizze einer einmaligen arabischen Stadt. Das Arabische Buch, Berlin.

Smith VL 1989. Hosts and guests - the anthropology of tourism. The University of Pennsylvania Press, Philadelphia. 
Stefanidaki E \& Lekakou M 2012. Generated economic impact on cruise destinations: the Piraeus case. In Papathanassis A, Lukovic T \& Vogel M (eds). Cruise tourism and society, 69-84. Springer Verlag, Berlin.

Stephenson M \& Ali-Knight J 2010. Dubai's tourism industry and its societal impact: social implications and sustainable challenges. Journal of Tourism and Cultural Change 8: 4, 278-292. http://dx.doi.org/10.1080/14766825.2010.521248.

Times of Oman 2014. Souq shops under scanner. Times of Oman, 02.04.2014.

Times of Oman 2015a. June 1. Cruise tours set to grow this season. Times of Oman, 01.06.2015.

Times of Oman 2015b. 8 most visited tourist places in Oman. Times of Oman, 26.03.2015.

Torres-Delgado A \& Saarinen J 2014. Using indicators to assess sustainable tourism development: a review. Tourism Geographies: An International Journal of Tourism Space, Place and Environment $16: 1,31-47$.

http://dx.doi.org/10.1080/14616688.2013.867530.

Urbanowicz C 1989. Tourism in Tonga revisited: continued troubled times? In Smith, VL (ed). Hosts and guests - the anthropology of tourism, 105-117. The University of Pennsylvania Press, Philadelphia.

Vanhove N 1997. Mass tourism - benefits and costs. In Wahab S \& Pigram JJ (eds). Tourism and sustainability in tourism, sustainability and growth, 5077. Routledge, London.

Wahab S \& Pigram JJ 1997. Tourism and sustainability - policy considerations. In Wahab S \& Pigram JJ (eds). Tourism and sustainability in tourism, sustainability and growth, 277-290. Routledge, London.

Wall G 1997. Sustainable tourism - unsustainable development. In Wahab S \& Pigram JJ (eds). Tour- ism and sustainability in tourism, sustainability and growth, 33-49. Routledge, London.

Ward C \& Berno T 2011. Beyond social exchange theory: attitudes towards tourists. Annals of Tourism Research 38: 4, 1556-1569.

http://dx.doi.org/10.1016/j.annals.2011.02.005.

Weaver A 2005a. Spaces of containment and revenue capture: 'super-sized' cruise ships as mobile tourism enclaves. Tourism Geographies: An International Journal of Tourism Space, Place and Environment 7: 2, 165-184.

http://dx.doi.org/10.1080/14616680500072398.

Weaver A 2005b. The McDonaldization thesis and cruise tourism. Annals of Tourism Research 32: 2, 346-366. http://dx.doi.org/10.1016/j.annals.2004.07.005.

Weeden C, Lester J-A \& Thyne M 2011. Cruise tourism: emerging issues and implications for a maturing industry. Journal of Hospitality and Tourism Management 18: 1, 26-29. http://dx.doi.org/10.1375/jhtm.18.1.26.

Wilkinson PF 1999. Caribbean cruise tourism: delusion? Illusion? Tourism Geographies 1: 3, 261-282. http://dx.doi.org/10.1080/14616689908721321.

Wood R 2000. Caribbean cruise tourism: globalization at sea. Annals of Tourism Research 27: 2, 345-370.

http://dx.doi.org/10.1016/S0160-7383(99)00073-0.

[WTTC] World Travel \& Tourism Council 2014. Travel \& tourism economic impact 2014 Oman. World Travel \& Tourism Council, London.

[UNWTO] World Tourism Organization 2010. Cruise tourism - current situation and trends. UNWTO, Madrid.

[UNWTO] World Tourism Organization 2013. World tourism barometer. Volume 11, statistical Annex 15. UNWTO, Madrid. 